\title{
Milli Eğitim Sisteminin Örgütsel Yapısı ve Maarif Müfettişleri Alt Sisteminin İşleyiş̧i
}

\author{
DOI: $10.26466 /$ opus.321994
}

\author{
$\underline{\text { Hasan Hüseyin Özkan }}^{*}$ - Yeliz Çelikten ${ }^{* *}$ \\ * Doç. Dr., Süleyman Demirel Üniversitesi, Eğitim Fakültesi, Isparta/Türkiye \\ E-Posta: huseyinozkan@sdu.edu.trＯRCID: 0000-0001-5249-1444 \\ ** Öğretmen, Yeliz Çelikten, Kepez İlkokulu, Kayseri/Türkiye \\ E-Posta: celikten@yahoo.com ORCID: 0000-0002-1825-7002
}

Öz

Bu çalışmanın amacl, milli eğitim sisteminin örgütsel yapısı, bu sistemin içinde yer alan maarif müfettişleri alt sisteminin durumu, yapı ve işleyişi, gelişimi ve değişimi sürecini incelemektir. Tarama modelinde bir çalışma olan bu araştırmada, milli eğitim sisteminin örgütsel yapısı ve bu sisteme bağlı kuruluşlar, bu kuruluşluların yapı ve işleyişi incelenmiştir. Merkezi yönetim odaklı olan milli eğitim sistemi; merkez teşkilatı, taşra teşkilatı, yurt dışı örgütü ve bağlı kuruluşları şeklinde ele alınmıştır. Ayrıca, örgütün amaçlarına ne ölçüde ulaştı̆̆ı, kaynaklarını ne derecede etkili kullanabildiği ve hizmet sürecinin nasıl geliştirilebileceği gibi sorularm cevaplanabilmesinde gerekli olan, denetleme ve değerlendirme sisteminin bir parçası şeklinde işleyen teftiş alt yapı sistemi ve işleyişi betimlenmeye ve değerlendirilmeye çalışllmıştır. Çalışmada, teftiş altyap sisteminin işleyişi ve müfettişlerle ilgili olumsuz algıyı destekleyen örnekler olduğu gibi tam aksine olumlu algıyı artırabilecek örneklerin de olduğu görülmüş, bu algının kırılabilmesi için müfettişler ve öğretmenlerin informal ortamlarda da bir araya gelmelerinin yararlı olacă̆ı sonuçlarına ulaşılmıştır.

Anahtar Kelimeler: Milli Eğitim Sistemi, Örgüt, Örgütsel yapı, Teftiş alt yapı sistemi, Müfettiş 


\title{
The Organizational Structure of National Education System and The Sub-structural Operations of Super- visors
}

DOI: 10.26466/opus.321994

\begin{abstract}
The aim of the study is to examine the organizational structure of national education system and the situation, structure, process, development and changes of supervisors who are the parts of this system. In this survey carried out in descriptive survey model, the organizational structure of national education system and the structure and working system of this instution are examined. Netional education system, having central management structure, is discussed according to central organization, provincial organization, abroad organization and related institution. Besides that, it is aimed to describe and evaluate sub-structural system of supervision which is necessary for answering the questions like how near the system is to its purposes, how efficient it uses the sources it have and how the function process can be improved and which is also working as a part of supervision and evaluation system and its working system. In this study it is seen that there are examples which supports the negative thoughts about supervision sub-instructions working style and supervisor on the other hand there are opposite examples which can promote positive thoughts about supervisors. It is concluded that to change these negative thoughts, it is advisable for teachers and supervisor getting together in informal settings.
\end{abstract}

Key Words : National Education System, Organization, Organizational Structure, Supervision sub-instructions, Supervisor 


\section{Giriş}

Eğitim konusu her ülke için vazgeçilmez bir unsurdur. Eğitimin amac1, kişileri hem kendi toplumuna hem de yaşadığımız dünyaya uyumlu bir birey haline getirerek, onları çağın gerektirdiği bilgi, beceri ve değerlerle donatmaktır (Toprak ve Bozgeyikli, 2011). Ülkelerin, toplumun hemen her düzeyi için yetişmiş ve gereken sayıda, yetkin ve eğitilmiş insan gücüne sahip olma konusunda her geçen gün giderek artan talep ve hassasiyetleri bu yargiyı kuvvetlendirmektedir. Bu toplumsal hassasiyetlerin etkili bir şekilde giderilmesinin yolunun, daha çok okullardan geçtiği söylenebilir (Yavaş Taşdelen, Aküzüm, Tan ve Uçar, 2015, akt: Doğan ve Semerci, 2016).

Bireylerin herhangi bir konuda doğru karar verebilmesi için ne gibi olanaklara sahip olduğunu bilmesi gerekir (Bozgeyikli, Toprak ve Derin, 2016). Klasik eğitim ve yönetim anlayışı, yerini bilgi çağının gereği olan, bilgi temelli, insan kaynakları geliştirilmesi anlayışına bırakmıştır. Aynı şekilde eğitim müfettişleri de bu değişimden etkilenerek, öğrenme-öğretme sürecini geliştiren, eğitim sisteminin nitelikli ürünler vermesini sağlayan, rehberliğe ağırlık veren temel unsurlar haline gelmiştir (Akbaba, 2013).

İnsanların bazı amaçları gerçekleştirmek amacıyla bir araya gelerek oluşturdukları yapılara örgüt denmektedir. Her örgüt kuruluş amacına göre farklı yapılara sahiptir. Örgütler, belirli hedefler doğrultusunda planlı bir şekilde önceden yapılandırılmış, hem uyum içerisinde faaliyetlerin yürütüldüğü hem de dış çevreleriyle bağlantılı sosyal varlıklardır (Daft, 2010; Çelikten, 2010b).

Eğitim örgütleri bulundukları çevre ve üstlendikleri işlevleri nedeniyle sürekli gelişmek durumundadırlar. Bugün demokratik toplumlarda insan kendi yönünü çizme ve yaşamı hakkında karar verme özgürlüğüne sahiptir (Bozgeyikli, Derin ve Toprak, 2016). Bireylerin, toplumların ve diğer 
paydaşların sürekli değişen gereksinimleri doğrultusunda eğitim örgütlerine yönelik beklentiler farklılaşmaktadır. Eğitim örgütleri de bu beklentilere örgütsel işleyiş, yapı ve süreçlerinde değişiklikler gerçekleştirerek yanıt vermeye çalışmaktadırlar.

Türk Eğitim Sistemi'nde yapılandırmacı eğitim yaklaşımı 2004-2005 eğitim-öğretim yılından itibaren ülke genelinde uygulamaya konulan, yeni insan modeli beklentisini karşılamaya dönük en önemli eğitim projelerinden biri olarak nitelendirilmektedir. Okullar toplumsal açık bir sistem olarak değerlendirildiğinde, eğitim sisteminin temel sistemi olarak dönüşüm süreçlerinde gerçekleştirilen bu önemli değişimin, sistemin tüm parçalarını etkilemesi kaçınılmazdır (Terzi, 2011; Çelikten, 2001).

Türk Eğitim Sisteminin örgüt yapısı "merkezi" yönetim odaklı bir örgüt yapısıdır. Cumhuriyetin kurulmasıla birlikte eğitim yönetiminde tüm yetkilerin merkezde toplandığı görülmektedir (www.inonu.edu.tr).

Tarihsel Süreç İçinde Milli Eğitim Bakanlığı:

1. 1923 'ten 27 Aralık 1935 tarihine kadar "Maarif Vekâleti",

2. 28 Aralık 1935'ten 21 Eylül 1941 tarihîne kadar "Kültür Bakanlığı",

3. 22 Eylül 1941 'den 9 Ekim 1946 tarihine kadar "Maarif Vekilliği",

4. 10 Ekim 1946'dan sonra "Millî Eğitim Bakanlığı",

5. 1950'den sonra "Maarif Vekâleti",

6. 27 Mayıs 1960 tarihinden sonra "Millî Eğitim Bakanlığı" adıyla çalışmalarını sürdürmüştür.

MEB bünyesinde, 91 yılda toplam 75 Bakan görev yapmıştır. Yani her bakan ortalama 1,2 yıl görev yapmıştır. Okullarda hiyerarşi kısa iken MEB'in hiyerarşisi uzundur. Bakan hiyerarşinin en tepesinde bulunur ve kendisine doğrudan bağlı olan Yükseköğretim Kurulu (YÖK) özel kalem müdürlüğü şeklinde görülen başkanlıkları ve müşavirlikleri yönetir. Diğer birimler ise müsteşara, müsteşar bakan yardımcısına, bakan yardımcısı da bakana bağlıdır. Dolayısıyla bakanın bir kararının kendisine doğrudan bağlı olmayan birimlere ulaşması için epey yol kat etmesi gerekmektedir. Örneğin bakanın aldığı bir karar sırasıyla bakan yardımcısı, 
müsteşar, il milli eğitim müdürlüğü, ilçe milli eğitim müdürlüğü ve okul müdürlüğüne iletilerek bir öğretmene ulaşmaktadır. Tabii il, ilçe ve okul müdürlüklerinde de hiyerarşilerin olduğu unutulmamalıdır. Taşra ve yurtdışı teşkilatları dışında kalan birimler merkez teşkilatını oluştururlar (Çelikten, 2003; Bozkuş, 2016).

Kararların alınmasında, hiyerarşinin hangi seviyesinin söz sahibi olduğu merkezileşme boyutu ile açıklanır (Daft, 2010). Bir örgütte önemli kararlar üst düzey yöneticiler tarafından alınıyorsa, o örgüt merkezileşmiş kabul edilir. Aksi halde örgüt merkezileşmemiş ya da âdem-i merkeziyetçi kabul edilir. Merkeziyetçi yapılar örgütün hayatta kalmasının arzulandığ 1 durumlarda tercih edilirken, âdem-i merkeziyetçi yapılar sorunlara çabuk çözüm üretilmesinin istendiği durumlarda tercih edilir (Schermerhorn, Hunt, Osborn, ve Uhl-Bien, 2010). Ülkemizin eğitim örgütlenmesi merkezileşmiştir. Eğitim politikalarının belirlenmesi ve öğretmenlerin atanması gibi önemli kararlar bakanlık tarafından alınmaktadır. Merkezileşmenin getirdiği tekdüzelik ile tüm okullarda aynı mevzuat ve program geçerli olup yerel farklılıklara ve ihtiyaçlara duyarsız kalınmaktadir.

Başaran (2006)'a göre Türk Eğitim Sisteminin örgüt yapısı üst sistem, aracı üst sistem ve temel sistemden oluşmaktadır.

- Üst sistem: MEB merkez örgütüdür.

- Aracı üst sistem: İl ve İlçe Milli Eğitim Müdürlükleri ve yurtdışı eğitim örgütüdür.

- Temel sistem: Eğitim hizmetlerini üreten okul öncesi, ilköğretim, ortaöğretim okulları, yaygın eğitim ve hizmet içi eğitim merkezleridir.

12.5.1992 tarih ve 21226 Sayılı Resmi Gazetede yayımlanan 3797 Sayılı "Milli Eğitim Bakanlığı'nın Teşkilat ve Görevleri Hakkındaki Kanun'a göre Milli Eğitim Bakanlığı:

(1) Merkez örgütü, (2) Taşra örgütü, (3) Yurtdışı örgütü ve (4) Bağlı kuruluşlar olarak örgütlenmiştir. 
Türkiye'de bütün eğitim kurumları Tevhid-i Tedrisat Kanunu (1924) ile bugünkü adı ile Milli Eğitim Bakanlığı (MEB) çatısı altında toplanmıştır. Sonraki dönemlerde gelişen ve değişen koşullara eğitim sistemimizin adaptasyonunun sağlanması amacıyla kanun hükmünde kararname, tüzük, yönetmelik, yönerge ve genelgeler yayımlanmıştır. Son olarak 14.09.2011 tarihli Resmi Gazete'de yayımlanan 652 sayılı Kanun Hükmünde Kararname (KHK) ile MEB Teşkilat Yapısı yeniden yapılandırılmıştır. Bu sayede işlevselliğini yitirmiş birimler kaldırılmış, aynı ya da benzer işi yapan birimler birleştirilerek merkez teşkilatı daha dinamik bir yapıya kavuşmuştur. Yenilenen teşkilat yapısıyla Bakanlık Müfettişlerinin Eğitim Denetçisi, Eğitim Müfettişleri Eğitim Denetmeni olarak göreve devam edecekleri görülmektedir. İl Eğitim Denetmenlerinin görev alanlarl; "İl düzeyinde bulunan her derece ve türdeki örgün ve yaygın eğitim kurumları ile il ve ilçe millî eğitim müdürlüklerinin rehberlik, işbaşında yetiştirme, denetim, değerlendirme, inceleme, araştırma ve soruşturma hizmetlerini yürütülmesi" şeklinde genişletilmiştir. Okulöncesi, İlköğretim ve Ortaöğretim kurumlarının rehberlik, işbaşında yetiştirme, denetim, değerlendirme, inceleme, araştırma ve soruşturma hizmetlerinin yürütülmesi görevleri il eğitim denetmen ve yardımcılarına verilmiştir (Çelikten, Şanal ve Yeni, 2005; Özdemir ve Boydak Özan, 2013)

Millî Eğitim Bakanlığı, taşrada 81 il ve 58'i büyük şehir merkez ilçesi olmak üzere 850 ilçede örgütlenmiştir. MEB'in, 21 eğitim müşavirliği ve 17 eğitim ataşeliği olmak üzere 22 ülkede temsilciliği bulunmaktadır. Güncel sayısal veriler Ek-1'de verilmiştir.

\section{Yöntem}

$\mathrm{Bu}$ araştırma, tarama modelinde bir çalışmadır. Tarama modeli, geçmişte ya da günümüzde halen var olan bir durumu, var olduğu şekliyle betimlemektir. Bu araştırmalarda; araştırmaya konu olan olay, birey veya nesne kendi koşulları içinde ve olduğu gibi tanımlanmaya çalışılır (Krathwohl, 
1993). Bu çalışmayla ilgili olarak uluslararası ve ulusal kaynaklar/çalışmalar incelenerek, var olan durumla ilgili tanımlamalar, yorumlamalar ve değerlendirmeler yapılmıştır.

Merkez Örgütü: Bakanlık makamı, Talim ve Terbiye Kurulu, ana hizmet birimleri, danışma ve denetim birimleri ile yardımcı birimlerinden oluşmaktadır. Meslekî ve Teknik Eğitim Araştırma ve Geliştirme Merkezi Başkanlığı (METARGEM) ile Projeler Koordinasyon Kurulu Merkezi Başkanlığı da merkez örgütü içerisinde yer almaktadır.

Yurt Dışı Örgütü: Milli Eğitim Bakanlığı, Kamu Kurum ve Kuruluşlarının Yurt Dışı Teşkilatları Hakkında Kanun Hükmünde Kararname esaslarına uygun olarak yurt dışında örgüt kurmaya yetkili kılınmıştır.

\section{Bağh Kuruluşlar}

Milli Eğitim Bakanlığının bağlı kuruluşları şunlardır:

1. Milli Eğitim Akademisi

2. Yüksek Öğrenim Kredi ve Yurtlar Kurumu Genel Müdürlüğü

\section{Taşra Örgüt Yapısı}

Milli Eğitim Bakanlığı'nın taşradaki uzantısı, illerde ve ilçelerde İl Milli Eğitim Müdürlükleri ile İlçe Milli Eğitim Müdürlükleri'dir. Ayrıca illerde İl Milli Eğitim Müdürlükleri bünyelerinde İlköğretim Müfettişleri Başkanlıkları oluşturulmuştur. Her ilde ve ilçede bir milli eğitim müdürlüğü bulunur, ilçe milli eğitim müdürlükleri görev ve hizmetleri yürütürken, il milli eğitim müdürlüklerine karşı da sorumludur. İl ve ilçelerin sosyal ve ekonomik gelişme durumları, nüfusları ve öğrenci sayıları göz önünde bulundurularak bu müdürlükler farklı tip ve statülerde kurulabilir ve farklı yetkiler verilebilir. İş durumuna ve ihtiyaca göre bakanlık ana hizmet birimleri, milli eğitim müdürlüklerine bağlı olarak ayrı il ve ilçe birimleri de kurabilir. 
İl Milli Eğitim Müdürlükleri bünyesinde İlköğretim Müfettişleri Başkanlığı oluşturulur. İlköğretim Müfettişleri en az dört yıl süreli yüksek öğrenimli öğretmenler arasından yarışma sınavı ile müfettiş yardımcısı olarak mesleğe alınırlar. Bu görevde üç yıllık yetişme dönemini takiben yapılacak yeterlik sınavını başaranlar ilköğretim müfettişi kadrolarına atanırlar. İlköğretim müfettişlerinin ve yardımcılarının görev, yetki ve sorumlulukları ile çalışma usulü, nitelikleri, yetişme şekli ve atanmalarına ilişkin esas ve usuller yönetmelikle düzenlenir (Can ve Çelikten, 2000).

Örgütler için denetim alt sistemlerinin önemi yadsınamaz. Bu sayede örgütsel amaçlardan sapmalar önlenir, örgütsel eylemlerdeki hata ve kusurlar düzeltilir, süreç geliştirilir. MEB denetim alt sistemi, görevsel anlamda pek farklı olmamakla birlikte birbirleri ile organik bağı olmayan, merkezde bakanlık teftiş kurulu ile taşrada ilköğretim müfettişleri başkanlıklarından oluşmaktadır (Duman, 1998; Çelikten, 2001b).

Örgütlerin varlıklarını sürdürebilmeleri, amaçlarını gerçekleştirebildikleri sürece söz konusu olmaktadır (Altınışık, 1997, akt: Kayıkçı, 2005).

Denetim kavramı on dokuzuncu yüzyılın yönetim anlayışının yansıması olan kaba ve basit bürokratik uygulamalardan, daha ince ve katılımcı demokratik uygulamalara doğru bir gelişim sürecinden geçmiştir. Günümüzde ise denetim kavramına, yansıtıcı uygulamalar ve yapılandırmacı öğrenme anlayışları içinde yaklaşılmaktadır (Glanz, 2000). 19. yüzyıldaki sanayi toplumunun eğitim anlayışında eğitim kurumları birer fabrika gibi görülüyordu. 20. yüzyılın büyük bir bölümünde de devam eden bu anlayışta eğitim kurumları, temsili demokrasi ve hiyerarşik denetime dayanan bir kontrol mekanizmasıyla idare edilegelmiştir. Klasik yönetim kuramlarının etkisinde, kontrol ve raporlamaya dayalı ve durum saptamayla s1nırlı olan klasik bir denetim türünün uygulandığı bu dönemde öğretmendenetçi ilişkileri ast-üst ilişkileri dışına çıkmamaktaydı (Çelikten 2004, Başar, 2000). Fakat büyük sosyal dönüşümlerin yaşandığı, bilginin üretiminin ve yayılmasının hızla arttığı, katılımcı demokrasinin yükselen bir değer olduğu ve örgütsel yapıların bunlara göre şekillendiği günümüzün 
sanayi ötesi toplumunda, teknolojik, politik, ekonomik ve sosyal değişimlerin yanında eğitim anlayışı da hızla değişmekte ve eğitimin denetiminin nasıl yapılması gerektiği konusunda yeni yaklaşımlar ortaya konulmaktadır. Çağdaş denetim yaklaşımlarında genel olarak göze çarpan ortak anlayışlardan bazıları şöyle ifade edilebilir: eşitlik ve ortaklık temeline dayalı ilişkiler, katılımcı karar verme, yansıtıcı dinleme ve uygulamalar, öğretmenin kendini değerlendirmesi ve kendini yönlendirmesi, okul temelli uygulamalar, eğitim-öğretimin etkililiğinin arttırılmasını amaçlayan etkinlikler, hiyerarşik değil işbirlikçi, didaktik değil diyaloga dayanan, cezalandırıcı değil destekleyici ve yargılayıcı değil betimleyici denetim (Glanz, 2000, akt: Karakuş, 2010).

Denetim, örgütsel eylemlerin kabul edilen amaçlar doğrultusunda, saptanan ilke ve kurallara uygun olup olmadığının anlaşılması süreci olarak düşünülebilir. Denetimin temel amacı, örgütün amaçlarını gerçekleştirme derecesini saptamak, daha iyi sonuçlar alabilmek için gerekli önlemleri almak ve süreci geliştirmektir. Denetim sistemi her karmaşık örgütte vardır. Bu örgütsel ve yönetimsel bir zorunluluktur (Aydın, 2014).

Her örgüt, bir ihtiyacı karşılamak için kurulur. Bu, onun varlık nedenidir. Örgütlerin varlıklarını sürdürebilmeleri; amaçlarına ulaşma derecelerine, etkili ve verimli olarak çalışabilmelerine, sürekli değişen çevreye uyum sağlayacak yapıları kurma becerilerine bağlıdır.

Her sistemin temel öğeleri; girdi, işlem ve çıktı alt sistemleridir. Bu alt sistemlerin uyumlu çalışması ve amaçlara ulaşma derecelerini sağlayacak kontrol-geri besleme (feed-back) veya denetim alt sistemi bulunur. Üründeki hataların, sapmaların daha oluşmadan saptanması, gerekli önlemlerin alınması ve sistemin geliştirilmesi için denetim (teftiş) alt sistemine ihtiyaç vardır. Çıktının istenilen nicelik ve nitelikte olması, enerjinin en rasyonel şekilde kullanılması teftiş sayesinde gerçekleşir. Örgütün amacına ulaşabilmesi iyi bir teftiş sisteminin oluşturulması ve işletilmesine bağlıdir (Arabacl, 1999). 
Tüm örgütlerde olduğu gibi eğitim örgütlerinde de etkililiğin sağlanması ancak planlanan ve ulaşılan durum arasındaki farkın saptanması, bunun sonucunda da eğitim-öğretim çalışmalarının geliştirilmesi ile mümkün olabilecektir. “Örgütün amaçlarına ne ölçüde ulaştığı, kaynaklarını ne derecede etkili kullanabildiği ve hizmet sürecinin nasıl geliştirilebileceği" gibi soruların yanıtlanabilmesi için eğitim-öğretim sürecinin denetlenmesi ve değerlendirilmesi gerekmektedir. Bu nedenle denetim, eğitim sistemlerinin vazgeçilmez bir süreci olagelmiştir.

Literatürde "denetim" ve "teftiş" kavramlarının bazen eş bazen de farklı anlamda kullanıldığı görülmektedir. Bu noktada bazı denetim ve teftiş tanımlarına bakmakta yarar olacaktır. Başaran $(2000,137)$ 'a göre denetim, planlanan örgütsel amaçlardan sapmayı önlemek için, örgütün işlemesini izleme ve düzeltme sürecidir. Sullivan ve Glanz $(2000,24)^{\prime}$ e göre ise denetim, öğretmenlerin öğrenci başarısını yükseltmek ve öğretimi geliştirmek amacıyla öğretimsel diyaloga katılması sürecidir. Bursalığlu $(2002,126)$ 'na göre teftiş, “kamu yararı adına davranışı kontrol etme yöntemi" olarak tanımlanabilir. Başka bir tanıma göre teftiş, istenilen ve gereksinim duyulan yer ve zamanda sağlanan, eğitimin her düzeyinde uygulanabilen bir mesleksel rehberlik ve yardım iken denetim, eğitim programlarının birçok yönünü etkileyen eşgüdümlenmiş bir teknik ve sosyal süreçtir (Aydın,1986,_7). Balcı (2005, 48)'ya göre eğitimde değerlendirme, teftiş/denetim adını alır.

Türk eğitim sisteminde teftiş ve değerlendirme alanına göre kurum ve ders teftişi olmak üzere iki gruba ayrılmaktadır. Kurum teftişi, teftişin işlevlerine göre yapılan tanımına uygun olarak eğitim kurumunun amaçlarını gerçekleştirmede insan ve madde kaynaklarının sağlanma, yararlanılma durumunun gözlenmesi, kontrol edilmesi ve ölçütlere göre değerlendirilmesidir. Ders teftişi ise bir eğitim kurumunda öğretici olarak görev alan öğretmenlerin öğretim ve eğitim etkinliklerdeki çalışmalarının gözlenmesi, incelenmesi ve değerlendirilmesidir (Çelikten ve Yeni, 2004; Taymaz, 2005, 28). Türkiye'de yükseköğretim kurumları hariç eğitim hizmeti 
veren tüm kurumların denetimi MEB tarafından yapılmaktadır (Milli Eğitim Bakanlığı Teftiş Kurulu Yönetmeliği, m. 60). İlköğretim öğretmenlerinin denetimleri "eğitim müfettişleri", ortaöğretim öğretmenlerinin denetimi ise ulusal-merkezi düzeydeki "bakanlık müfettişleri" tarafından yapılmaktadır (Akt: Demirkasımoğlu, 2011).

Müfettiş, öğretmenlerin öğretmeni olarak öğretmenlere ve yöneticilere mesleki yardımda bulunur. Öğretmenlerin arzu edilir bir öğretim yapmaları ve öğrenciler için uygun öğrenme ortamları hazırlamaları için gerekli yardımda bulunmaları müfettişlerin en önemli işlevlerindendir. Teftiş alt sisteminin, eğitim sistemi içindeki en temel işlevi, eğitim-öğretimi geliştirme ve değerlendirmedir (Öz, 2003, akt: Yaman, 2010).

\section{Müfettişlerin Görevleri}

Müfettişlerin görevleri çeşitli yazarlar tarafından, değişik görüşlerle ele alınmıştır. Bir görüşe göre bu görevleri rehberlik, koordinatörlük ve kaynaklık olarak üç grupta toplamak mümkündür. Bu görevlerin gerektirdiği eylemler ise şöyle sıralanabilir (Bursalığlu, 2002, akt: Memişoğlu, 2016):

1. Öğretmen ve yöneticilerin, çocukları daha iyi anlamasını sağlamak,

2. Öğretmenin bireysel ve mesleksel gelişmesine yardım etmek,

3. Öğretim materyallerinin daha verimli kullanılmasında ilgililere yardım etmek,

4. Öğretim yöntemlerinin geliştirilmesinde öğretmene yardım etmek

5. Öğretmenin öğrencilerini ve kendini değerlendirmesine yardım etmek

6. Eğitim girişimi ile ilgili herkese, okuldaki başarıları anlatmak ve tanıtmak.

Eğitim sisteminde müfettişlerin görevlerini yerine getirebilmeleri ve rollerini oynayabilmeleri için belli yeterlikleri kazanmış olmaları gerekir. Teftiş sisteminde müfettişin yerini, kendisine yasal olarak verilen görevler, görevleri yerine getirme süreçleri, oynadığı roller ve bu rolleri oynarken gösterdiği davranışlar belirler (Taymaz, 2005, akt: Memişoğlu, 2016). 
Milli Eğitim Bakanlığı Rehberlik ve Denetim Başkanlığı ile Maarif Müfettişleri Başkanlıkları Yönetmeliğinde müfettiş ve müfettiş yardımcılarını görevleri, rehberlik, denetim, inceleme ve soruşturma olarak belirtilmiştir. (MEB, 2014). Aynı yönetmelikte Bakanlığın görev alanına giren konularda Bakanlık personeline, okul ve kurumlara, özel öğretim kurumlarına, kamu kurum ve kuruluşlarına, gönüllü kuruluşlar ile gerçek ve tüzel kişilere rehberlik yapılacağı husus vurgulanarak yönetmelikte belirtilen rehberlik hizmetlerinin çeşitleri şu şekilde belirtilmiştir (MEB, 2014):

a) Önleyici rehberlik; denetimlerden bağımsız veya denetim esnasında, kurumsal ve bireysel performansi etkilemesi muhtemel sorun alanlarına yönelik her türlü kaynağın etkin kullanımı ve verimlilik esaslarına dayalı olarak hedefleri gerçekleştirmeye yönelik faaliyet ve işlem süreçlerinin sistemli ve düzenli bir biçimde değerlendirilmesi ve geliştirilmesi amacıyla yapılır.

b) Düzeltici ve iyileştirici rehberlik; denetim esnasında, kurumsal ve bireysel düzeyde yapılan izleme ve değerlendirme sonucunda ortaya çıkan sorun alanlarının düzeltilmesi ve iyileştirilmesi amacıyla yapilir.

c) Geliştirici rehberlik; denetimlerden bağımsız, gelişimin sürekliliği ve yaşam boyu öğrenme esasına dayalı, kurumsal ve bireysel potansiyelin en üst düzeyde değerlendirilebilmesi amacıyla destekleyici düzeyde yürütülen rehberlik çalışmasıdır.

Yönetmelikte denetim faaliyetlerinde, yolsuzluk ve usulsüzlükleri önleyici, eğitici ve rehberlik yaklaşımı ile iyileştirici ve geliştirici katkı sağlamanın esas olduğuna vurgu yapılarak denetim hizmetlerinin çeşitleri aşağıdaki şekilde ele alınmıştır (MEB, 2014):

a) Süreç ve sonuç denetimi; Bakanlık tarafından veya bakanlığın denetiminde sunulan hizmetlerin kontrol ve denetiminin ilgili birimlerle işbirliği içinde yapılması, süreç ve sonuçlarının mevzuata, önceden belirlenmiş amaç ve hedeflere, performans kriterlerine ve kalite standartlarına göre analiz edilmesi, karşılaştırılması ve ölçülmesi, 
kanıtlara dayalı olarak değerlendirilmesi, elde edilen sonuçların rapor haline getirilerek ilgili birimlere ve kişiler iletilmesidir.

b) Performans denetimi; yönetimin bütün kademelerinde gerçekleştirilen faaliyeteler ile sonuçlarının etkililiğinin, ekonomikliğinin ve verimliliğinin belirlenen hedef ve göstergelerle belirlenmesidir.

c) Sistem denetimi; denetlenen birimin yönetim süreçleri, faaliyet ve işlemleri ile iç kontrol sisteminin, organizasyon yapısına katkı sağlayıcı bir yaklaşımla analiz edilmesi; kaynakların amacı doğrultusunda etkili, ekonomik ve verimli kullanılması ile elektronik bilgi sistemlerinin sürekliliğinin ve güvenirliğinin incelenmesi ve değerlendirilmesidir.

d) Mali denetim; denetlene birimin gelir, gider, varlık ve yükümlülüklerine ilişkin hesap ve işlemlerin doğruluğunun; mali faaliyet, mali yönetim ve kontrol sistemlerinin, mali sistem ve tabloların güvenirliğinin, yolsuzluk ve usulsüzlükleri önleyici, eğitici ve rehberlik yaklaşımını ön plana çıkaran bir anlayışla incelenmesi ve değerlendirilmesidir.

e) Uygunluk denetimi; denetlenen birimin faaliyet ve işlemlerinin ilgili kanun tüzük ve yönetmelik ve diğer mevzuata uygunluğunun incelenmesi ve değerlendirilmesidir.

Yukarıda verilen görevler göz önünde bulundurulduğunda müfettişler yaklaşık 4 yıldır sınıf içi denetim yapmamaktadır, yalnızca kurum içi denetim yapmaktadır. Buna rağmen öğretmenlerin müfettiş algısı değişmemiştir. Öğretmenlerin genel olarak müfettiş algıları korku yönündedir.

Kayseri İl Milli Eğitim Müdürlügü Maarif Müfettişlerinden Mehmet Yaşar'ın bu konuda aktardığı anısı şu şekildedir:

"2015 yılında yeni programın tanıtımı amacıyla hizmet içi eğitime gittik. Öğretmenlere yeni programı tanıtıyoruz. Seminerin sonuna doğru anılardan da bahsederken "Ben 3 kıyafetten korkarım. Asker, polis, ormancı" dedim. Ormancı köyünde büyüdü̈̆̈̈m için 
ormancılarm bende böyle bir etkisi olduğundan bahsettim. Bir ö ̆̆retmen arkadaş söz alarak " Hocam sen onu dört yap. Bir de müfettişleri ekle" dedi. Doğru söylüyorsun diyerek öğretmenlik dönemim de kendimin de korktuğumu söyledim."

Bir diğer müfettişimizin de yaşadığı anı yine bu algıyı kanıtlar niteliktedir. Olayı şu şekilde aktarmıştır:

"Kuralcilığı ve sert mizacıyla nam salmış, öğretmenlerin adını duyduğunda endişeye kapıldığı bir meslektaşımla çalışma firsatı buldum. Bir gün teftiş için gittiğimiz okulun müdür odasinda gerekli denetlemeleri yapıyorduk. Fakat öğretmenlerdeki gerginliği fark etmemek mümkün değildi. Kapı birden bire çaldı ve okul öğretmenlerinden bir bayan içeri girdi. Teftişini hangi müfettişin yapacă̆ın sordu. Okul müdürü kısa bir şaşkınlı̆̆ın ardından malum arkadaşımızın yapacağın söyledi. Bayan öğretmen şaşkınlık ve korku içerisinde "Ama ben hamileyim, bu strese dayanamam!" diye ba$\breve{g} ı r d \imath$ ve ağladı. Ne diyeceğimizi bilemedik. Maalesef böyle örnekler çoğaldıkça müfettişlik soğuk bir meslek olmaktan çıkamayacak."

Bu ve benzeri örneklerin yanı sıra bu algıyı kıran olumlu örnekler de mevcuttur. Adıyaman İl milli Eğitim Müdürlüğü Maarif Müfettişlerinden Murat Karakulak:

“Şırnak'ta müfettişlik yaparken Cizre'de otobüse bindim. Yalova'ya gidiyordum. Yanıma bir beyefendi oturdu. Öğretmen olduğunu bilmiyordum. Muhabbet etmeye başladık. Yol boyunca konuştuk. "Nerden geliyorsun?" dedim. "İdil'den geliyorum" dedi. "Ne iş yapıyorsun?" dedim, "Öğretmenim" dedi. Hafta ortası Salı günüydü. "Öğretmen isen okulu ne yaptın, nasil hafta ortasinda okuldan ayrilıyorsun?" dedim. "Bir arkadaşımın dü̆̈̈̈nü var Bursa'da, oraya gidiyorum" dedi. Ben müfettiş olduğumu söylemedim, kendimi tanıtmadım. "Peki bir müfettiş gelse okuluna durumu görse, okulda olmadı̆̆ın bilse izin ve rapor almadan, ne olacak?" dedim. Argo bir şekilde konuşarak "Aman kim bu kışın ortasında İdil'e, İdil'in köyüne gelecek de beni bulacak?" dedi. O Bursa'da indi ben 
Yalova'ya kadar devam ettim. Gün oldu biz denetime gittik İdil'e. Kapıda beni görünce o öğretmen bandı biraz geriye sardı, hatırladı beni. Kıpkırmızı oldu. Köşeye çektim. Bizim grup başkanı biraz acımasizdır. "Bak ne ben seni gördüm, ne sen beni gördün" dedim. Hiçbir şey olmamış gibi davrandım. Bunu şunun için söyledim. Ĕ̆ger gerçekten çalışan bir öğretmense görmemezlikten gelecektim, çalışmamışsa da dile getirecektim. Öğretmen gerçekten çok güzel çalışmış. Hiç kimseye söylemedim ve olay kapandı." şeklinde başından geçen bir olayı aktarmıştır.

Bir başka örnekte ise Kayseri İl milli Eğitim Müdürlüğü Maarif Müfettişlerinden Erdal POTUR:

“Develi'de bulunan bir dă̆ köyüne teftişe gittik. Antalya'dan buraya tayin olmuş genç bir aday bayan öğretmenimiz ile karşılaştık. İlk başlarda köyde tek başına kalmasına rağmen yaşanan bazı durumlardan dolayı Develi'den gidiş dönüş yaptığını söyledi. Develi ve köy arası 55-60 km var.

"Neden burayı yazdin?"

"İnternette resimlerine baktım. Yeşillik ve akarsu olduğunu görünce yazdım" dedi. Daha sonra sinıfa geçtiğimizde simıf yönetiminin çok zayıfolduğunu tespit ettik. Aday öğretmen olduğu için ayda bir denetime gidiyoruz. Bir ay sonra gittik ve hiçbir gelişme olmadlğın gözlemledik bunun üzerine diğer arkadaşım:

"Sen bu şekilde gidersen asil öğretmenliğge geçemeden bu mesleğe veda edersin "dedi. Öğretmenimizin buna çok üzüldüğ̈̈nü gördüm. Bunun üzerine ben de:

"Sen becerikli bir kıza benziyorsun ama anladığım kadarıla henüz nasıl yapacağını bulamamışsın. Sen bu okulu çekip çevir bir sene. Söz seni Develi merkezde bir okula görevlendirme yaptırtacağım" dedim. Gözlerinin içi parladı. Nitekim bir sene o okulda önemli sayllabilecek bir ilerleme kaydetti. Ben de sözümde durdum. Develi'ye görevlendirildi. Bir sene sonra Develi'ye 7-8 km uzaklıkta bir köye tayini çıtı." 


\section{Sonuç}

Yaklaşık 4 yıldır sınıf içi denetlemeler yapılmamasına rağmen öğretmenlerin olumsuz düşünceleri değişmediği görülmektedir. Ancak verilen örneklerde de görüldüğü üzere müfettişler hakkındaki olumsuz algıyı destekleyen örnekler olduğu gibi tam aksine olumlu algıyı artırabilecek örnekler de mevcuttur. Bu algının kırılabilmesi için müfettişler ve öğretmenlerin informal ortamlarda da bir araya gelmelerinin yararlı olacağı düşünülmektedir.

Öztürk ve Gök (2010) yaptıkları araştırmada okul müdürleri, eğitim denetmenlerinin denetimde müdür koltuğuna oturmalarını, yöneticilerin psikolojik durumunu bilmemelerini, denetim sırasında eleştirilerinin olmamasını, yöneticiyi öğretmenlerin ve diğer çalışanların yanında eleştirmesini orta düzeyde sorun olarak algılamışlardır. Büyükışık'ın (1989) yaptığ1 araştırmada ilköğretim okullarının denetiminde denetmenlerle öğretmenler arasında iletişim sorunları yaşandığı saptanmıştır. Eğitim sistemimizde denetmenlerin soruşturma, denetim ve rehberlik görevlerini bir arada yürütmesi yani denetmenlerin "savcllık, yargıçlık ve rehber" rollerini bir arada yapması denetmenlerin denetimde etik ilkelere bağlı olarak hareket etmesini daha da önemli hale getirmektedir. Örneğin denetmenin gerek soruşturma ve gerekse öğretmeni değerlendirme esnasında adil olması, ön yargılı olmaması denetimin saygınlığı açısından önemlidir. Bilir (1991) "Türk eğitim sisteminde teftiş alt sisteminin yapı ve işleyişi" araştırmasının sonucunda denetimin objektif olması, soruşturma görevinin adil yapılması konusunda öneriler getirmiştir. Uğurlu (2010a) öğretmenlerin eğitim denetmenlerinin etik davranışlarına ilişkin görüşlerini saptamaya yönelik araştırmasında öğretmenler denetmenleri gizliliğe önem verme, işlerini hukuka uygun yapma, özel ihtiyaçlarını öğretmen ve okul yoluyla giderme konusunda en yüksek; adil olma, tarafsız olma ve kendini yenileme konularında en düşük düzeyde değerlendirmişler- 
dir. Dağlı ve Akyıldız’ın (2009) araştırmasına göre öğretmenler eğitim denetmenlerini değerlendirmede objektif olma ve öğretmenleri tanıma konusunda yeterli görmemektedirler. Aksoy'un (1998) “Eğitim denetiminde etik boyut" adlı çalışmasında denetimde etik ilkeler olarak şunlar belirlenmiştir: "kişisel farklılıklara karşı duyarlı ve saygı, toplumsal değerlere karşı duyarlı ve saygılı, yenileşme ve değişmeye açık, yönetici ve öğretmenlere değerlerini empoze etmeme, duygusal iletişim ve etkileşimden kaçınma, gizlilik ve bireylere zarardan kaçınma, mesleki yeterlilik ve dürüstlük, açıklık (şeffaflık), insansal ve bilimsel sorumluluk". Pehlivan'ın (1997) çalışmasında da hoşgörü, adalet, sorumluluk, dürüstlük, demokrasi ve saygı boyutları ön plana çıkmıştır. Kahraman'ın (2003) araştırmasina göre, "ilköğretim okulu yönetici ve öğretmenleri, eğitim denetmenlerinin, soruşturmalarda tanık olacak kimselere, yönlendirmede bulunmazlar, mesleki konum ve yetkilerini kendi politik amaçları için kullanmazlar, öğrencilerin yanında öğretmenleri eleştirmekten kaçınırlar, savunma ve görüşleri alınan bireye nezaketle yaklaşırlar" ilkelerine "bazen" uyduklarını belirtmişlerdir (Akt: Kayıkçı, 2012)

Eğitim sürecinin daha etkili olması, öğretmenlere yapılacak rehberliğin kalitesiyle mümkündür. Bu açıdan öğretmenlerin meslekî gelişimlerine katkı sağlamanın eğitimde çok yönlü bir adım sağlayacağı söylenebilir. Öğretmenlere bu rehberliği yapabilecekler arasında ilk sırada okul yöneticileri ve meslektaşlarla birlikte maarif müfettişleri gelmektedir (Korkmaz ve Özdoğan, 2005; Çelikten, 2008)._Etkili bir teftiş için maarif müfettişlerinin; takım çalışmalarını koordine etme, kısa ve uzun dönemli planlar yapma, kişiler arası ilişkileri yönetme becerileri, öğretim becerileri, s1nıf yönetimi ve meslekî rol modelleri gibi temel yeterlilikler, sözel iletişim, stres ve zamanı yönetme, bireysel kararları yönetme, problemleri anlama, tanımlama ve çözme, vizyon sahibi olma ve amaç oluşturma gibi özelliklere sahip olması gerekmektedir (Whetten ve Cameron 1993; Hunt ve Baruch 2003; Çelikten, 2005; Çelikten, 2010). Sullivan ve Glanz (1999) teftişi, 
öğrencinin başarısını artırma ve öğretimi geliştirme amacına yönelik öğretmenlerin katıldığı öğretimsel diyalog süreci olarak tanımlamıştır.

Aydın (2007)'a göre öğretme ve öğrenme ortamında etkili bir etkileşim için gerekli, uygun koşulların hazırlanmasına özel bir önem verilmeli ve etkili etkileşimin ön şartı olan iletişim sisteminin kurulmasının da teftişte bir görev olduğunun farkına varılmalıdır. Bunun için, müfettişlerin etkileşimde bulundukları herkesle iyi bir iletişim içinde olması gerekmektedir. Yalçınkaya (1992), iyi iletişim kurulması sonucunda teftişten beklenen faydanın elde edilerek örgütte verimin artacağını ve böylece örgütün gelişmesinin sağlanacağını belirtmiştir. Çetinkanat ve Sağnak (2010), karşılıklı etkilemenin, iletişimi anlamak için en temel kavram olduğunu ifade etmiştir. Eğitimin temeli iletişime dayandığı ve kurumlarda amaçlanan öğretimin yapılabilmesi için iletişim kurmak gerekmektedir (Gökçe ve Baskan 2012; Çelikten ve Çelikten, 2007). Aydın (2007)'a göre de iletişim, yönetim sürecinin önemli bir ögesidir ve eğitim liderliği rolü oynayan denetmenin karmaşık ilişkileri düzenlemek ve sürdürmek zorunluluğu adına daha etkili iletişim kurması mecburidir (Akt: Yıldız, 2015)

Eğitimde müfettişten beklenen başlıca görev, okuldaki eğitim-öğretim çalışmalarının daha verimli olabilmesi için bu etkinliklerde öğretmene yol göstermektir (Döş, 2005). Bennett (2006), öğretmenlerle müfettişler arasındaki etkileşimde zorunlu bir iletişim ve işbirliği olduğunu söylemiştir. Döş (2010), ise, müfettiş ve öğretmen arasındaki iletişimin bazı tutum ve yaklaşımlardan dolayı sarsılmasının, teftişin etkililiğini kaybedeceğini ifade etmiştir. Özetle, etkili bir teftiş için etkileşimin; etkileşim için de iletişimin sağlıklı biçimde kurulması sağlanmalıdır (Akt: Yıldız, 2015). 


\section{EK:1}

Zorunlu Çalışma Süresini Tamamlayan Maarif Müfettişlerinin 2016 yılı yer değiştirmelerine Esas İllerin Maarif Müfettişi İhtiyacı ve Yer Değiştirme İşlemleri

\begin{tabular}{|c|c|c|c|c|c|c|}
\hline 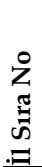 & 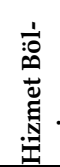 & क्ष心 & 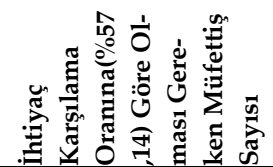 & 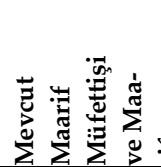 & 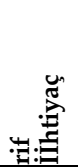 & 茎 \\
\hline 1 & 1 & Adana & 59 & 70 & 0 & 11 \\
\hline 2 & 4 & Adıyaman & 29 & 31 & 0 & 2 \\
\hline 3 & 2 & Afyon & 30 & 27 & 3 & 0 \\
\hline 4 & 5 & Ağr1 & 29 & 2 & 27 & 0 \\
\hline 5 & 3 & Amasya & 15 & 16 & 0 & 1 \\
\hline 6 & 1 & Ankara & 137 & 379 & 0 & 242 \\
\hline 7 & 1 & Antalya & 65 & 64 & 1 & 0 \\
\hline 8 & 4 & Artvin & 9 & 6 & 3 & 0 \\
\hline 9 & 1 & Aydın & 35 & 33 & 2 & 0 \\
\hline 10 & 1 & Balıkkesir & 37 & 37 & 0 & 0 \\
\hline 11 & 2 & Bilecik & 9 & 9 & 0 & 0 \\
\hline 12 & 5 & Bingöl & 15 & 6 & 9 & 0 \\
\hline 13 & 5 & Bitlis & 22 & 4 & 18 & 0 \\
\hline 14 & 2 & Bolu & 12 & 13 & 0 & 1 \\
\hline 15 & 2 & Burdur & 13 & 13 & 0 & 0 \\
\hline 16 & 1 & Bursa & 67 & 77 & 0 & 10 \\
\hline 17 & 2 & Çanakkale & 17 & 22 & 0 & 5 \\
\hline 18 & 3 & Çankırı & 9 & 11 & 0 & 2 \\
\hline 19 & 2 & Çorum & 22 & 21 & 1 & 0 \\
\hline 20 & 2 & Denizli & 34 & 38 & 0 & 4 \\
\hline 21 & 4 & Diyarbakır & 57 & 25 & 32 & 0 \\
\hline 22 & 2 & Ediirne & 14 & 17 & 0 & 3 \\
\hline 23 & 4 & Elazı̆g & 22 & 26 & 0 & 4 \\
\hline 24 & 4 & Erzincan & 12 & 8 & 4 & 0 \\
\hline 25 & 4 & Erzurum & 39 & 15 & 24 & 0 \\
\hline 26 & 1 & Eskişehir & 24 & 28 & 0 & 4 \\
\hline 27 & 1 & Gaziantep & 51 & 43 & 8 & 0 \\
\hline 28 & 4 & Giresun & 17 & 18 & 0 & 1 \\
\hline 29 & 4 & Gümüşhane & 8 & 6 & 2 & 0 \\
\hline 30 & 5 & Hakkari & 14 & 0 & 14 & 0 \\
\hline 31 & 2 & Hatay & 50 & 45 & 5 & 0 \\
\hline 32 & 2 & Isparta & 19 & 21 & 0 & 2 \\
\hline 33 & 1 & Mersin & 52 & 55 & 0 & 3 \\
\hline 34 & 1 & İstanbul & 283 & 267 & 16 & 0 \\
\hline 35 & 1 & İzmir & 107 & 143 & 0 & 36 \\
\hline
\end{tabular}




\begin{tabular}{|c|c|c|c|c|c|c|}
\hline 36 & 5 & Kars & 19 & 0 & 19 & 0 \\
\hline 37 & 3 & Kastamonu & 15 & 15 & 0 & 0 \\
\hline 38 & 1 & Kayseri & 41 & 42 & 0 & 1 \\
\hline 39 & 2 & Kırklareli & 12 & 12 & 0 & 0 \\
\hline 40 & 3 & Kırşehir & 3 & 13 & 0 & 1 \\
\hline 41 & 1 & Kocaeli & 1 & 44 & 0 & 0 \\
\hline 42 & 2 & Konya & 70 & 63 & 7 & 0 \\
\hline 43 & 3 & Kütahya & 21 & 18 & 3 & 0 \\
\hline 44 & 3 & Malatya & 31 & 47 & 0 & 16 \\
\hline 45 & 1 & Manisa & 43 & 43 & 0 & 0 \\
\hline 46 & 4 & Kahramanmaraş & 39 & 46 & 0 & 7 \\
\hline 47 & 5 & Mardin & 34 & 9 & 25 & 0 \\
\hline 48 & 1 & Muğla & 32 & 32 & 0 & 0 \\
\hline 49 & 5 & Muş & 23 & 3 & 20 & 0 \\
\hline 50 & 2 & Nevşehir & 14 & 14 & 0 & 0 \\
\hline 51 & 2 & Niğde & 16 & 19 & 0 & 3 \\
\hline 52 & 3 & Ordu & 25 & 32 & 0 & 7 \\
\hline 53 & 3 & Rize & 14 & 13 & 1 & 0 \\
\hline 54 & 1 & Sakarya & 30 & 30 & 0 & 0 \\
\hline 55 & 2 & Samsun & 44 & 49 & 0 & 5 \\
\hline 56 & 5 & Siirt & 18 & 2 & 16 & 0 \\
\hline 57 & 3 & Sinop & 10 & 11 & 0 & 1 \\
\hline 58 & 4 & Sivas & 26 & 27 & 0 & 1 \\
\hline 59 & 1 & Tekirdağ & 24 & 24 & 0 & 0 \\
\hline 60 & 3 & Tokat & 25 & 25 & 0 & 0 \\
\hline 61 & 2 & Trabzon & 28 & 28 & 0 & 0 \\
\hline 62 & 5 & Tunceli & 6 & 1 & 5 & 0 \\
\hline 63 & 4 & Şanlıurfa & 71 & 29 & 42 & 0 \\
\hline 64 & 2 & Uşak & 14 & 14 & 0 & 0 \\
\hline 65 & 4 & Van & 46 & 13 & 33 & 0 \\
\hline 66 & 3 & Yozgat & 21 & 22 & 0 & 1 \\
\hline 67 & 3 & Zonguldak & 21 & 13 & 8 & 0 \\
\hline 68 & 3 & Aksaray & 18 & 17 & 1 & 0 \\
\hline 69 & 4 & Bayburt & 7 & 4 & 3 & 0 \\
\hline 70 & 3 & Karaman & 11 & 11 & 0 & 0 \\
\hline 71 & 2 & Kırıkkale & 13 & 17 & 0 & 4 \\
\hline 72 & 5 & Batman & 26 & 7 & 19 & 0 \\
\hline 73 & 5 & Şırnak & 22 & 2 & 20 & 0 \\
\hline 74 & 3 & Bartın & 9 & 7 & 2 & 0 \\
\hline 75 & 5 & Ardahan & 8 & 3 & 5 & 0 \\
\hline 76 & 5 & Iğdır & 11 & 2 & 9 & 0 \\
\hline 77 & 1 & Yalova & 10 & 10 & 0 & 0 \\
\hline 78 & 3 & Karabük & 10 & 9 & 1 & 0 \\
\hline 79 & 3 & Kilis & 8 & 10 & 0 & 2 \\
\hline 80 & 3 & Osmaniye & 20 & 22 & 0 & 2 \\
\hline \multirow{2}{*}{81} & 2 & Düzce & 15 & 15 & 0 & 0 \\
\hline & & Toplam & 2514 & 2485 & 408 & 382 \\
\hline
\end{tabular}




\section{EK 2:}

\section{Milli Ĕ̆itim Örgün Ĕ̆itim 2016 İstatistikleri}

\begin{tabular}{ll}
\hline Öğretmen Sayısı & 993.794 (863.126 resmi kurum; 130.868 özel ku- \\
& rum) \\
Okul öncesi öğretmen sayısı & 32.463 \\
İlkokul öğretmen sayısı & 302.961 \\
Ortaokul öğretmen sayısı & 322.680 \\
Ortaöğretim öğretmen sayısı & 335.690 \\
Özel eğitim öğretmen sayısı & 11.595 \\
\hline
\end{tabular}

\section{KAYNAKÇA}

Akbaba, A. (2013). Okul müdürlerinin, eğitim müfettişlerinin denetim olgusu ve süreçleriyle ilgili algisı. Electronic Turkish Studies, 8(12).

Aksoy, H. (1998). Eğitim denetiminde etik boyut. İnönü Üniversitesi, Malatya: Yayımlanmamış Yüksek Lisans Tezi

Arabacı, İ. B., ve Müfett, M. E. M. İ. (1999). Meb teftiş politikası (I). Kuram ve Uygulamada Ĕ̆itim Yönetimi, 20(20), 545-575.

Aydın, M. (1986). Çă̆daş eğitim denetimi. IM Eğitim Araştırma Yayın Danışmanlık. Ankara.

Aydın, A. (2007). Eğitim psikolojisi. Tek Ağaç Eylül Yayıncılık, Ankara.

Aydın, A., ve Uysal, Ş. (2014). Türkiye'de eğitim yönetimi teftişi planlaması ve ekonomisi alanındaki doktora tezlerinin incelenmesi. Abant İzzet Baysal Üniversitesi Ĕ̆itim Fakültesi Dergisi.

Balcı, A. (2005). Açıklamalı eğitim yönetimi terimleri sözlüğü, Tek Ağaç Yayınları, Ankara.

Başar, H. (2000). Ĕ̆itim denetçisi. Pegema Yayıncılık, Ankara.

Başaran, İ. E. (2000). Eğitim yönetimi: Nitelikli okul. Feryal Matbası, Ankara.

Başaran, İ. E. (2006). Türk eğitim sistemi ve okul yönetimi, Ekinoks Yayınları, Ankara.

Bennett, T. (2006). Clinical supervision marriage: A Matrimonial metaphor for understanding the supervisor-teacher relationship. 20 
Mayıs 2017, Http://www.Eric.Ed.Gov/Erıcwebportal/Contentdelivery/Servlet/Ericservlet?Accno=Ed480183.

Bilir, M. (1991). Türk eğitim sisteminde teftiş alt sisteminin yapı ve işleyişi. Ankara Üniversitesi, Ankara: Yayımlanmamış Doktora Tezi.

Bozgeyikli, H., Derin, S. ve Toprak, E. (2016). Üniversite öğrencilerinin mesleki değer algiları. International Journal of Contemporary Educational Studies, 2(1), 139-156.

Bozgeyikli, H., Toprak, E. ve Derin, S. (2016). Öğretmen adaylarının mesleki değer algılarının sıralama yargılarıyla ölçeklenmesi. Hak-İş Uluslararası Emek ve Toplum Dergisi, 5(11), 204-225.

Bozkuş, K.(2016). Örgüt yapısı ve okullar. Kesit Akademi Dergisi (The Journal Of Kesit Academy) Y11: 2, Sayı:4, Haziran 2016, S. 236-260

Bursalıŏlu, Z. (2002). Okul yönetiminde yeni yapı ve davranış. Pegem A Yayıncilık, Ankara.

Büyükışık, M. (1989). İlköğretim denetçilerinin rehberlik etkinliklerini gerçekleştirme düzeyleri. Hacettepe Üniversitesi, Ankara: Yayımlanmamış Yüksek Lisans Tezi.

Can, N., ve Çelikten, M. (2000). Alt düzey personelin güç kaynakları: Erciyes Üniversitesi Örneği. Kuram ve Uygulamada Eğitim Yönetimi, 22(22), 269-290.

Çelikten, M. (2001). Okul yöneticilerinin problem çözme becerileri. Kuram ve Uygulamada Eğitim Yönetimi Dergisi, 7(3), 297-309.

Çelikten, M. (2001). Etkili okullarda karar süreci. Erciyes Üniversitesi Sosyal Bilimler Enstitüsü Dergisi, 11(2), 263-274.

Çelikten, M. (2003). Okul kültürünün şekillendirilmesinde müdürün rolleri. Türk Ĕ̆itim Bilimleri Dergisi, 1(4).

Çelikten, M. (2004). Okul müdürü koltuğundaki kadınlar: Kayseri ili örneği. Sosyal Bilimler Enstitüsü Dergisi, 17(2), 91-118

Çelikten, M., ve Yeni, Y. (2004). Okul müdürlerinin liderlik ve yöneticilik özelliklerinin cinsiyet açısından değerlendirilmesi. Kastamonu Ĕ̆itim Dergisi, 12(2), 305-314. 
Celikten, M. (2005). A perspective on women principals in Turkey. International Journal of Leadership in Education, 8(3), 207-221.

Çelikten, M., Şanal, M., ve Yeni, Y. (2005). Öğretmenlik mesleği ve özellikleri. Erciyes Üniversitesi Sosyal Bilimler Enstitüsü Dergisi, 19(2), 207237.

Çelikten, M., ve Çelikten, Y. (2007). Televizyon programlarında çizilen öğrenci, öğretmen ve yönetici profilleri. Sosyal Bilimler Enstitüsü Dergisi, 23(2), 369-378.

Çelikten, M. (2008). Öğretmenlik mesleğinde yeni model arayışları. Selçuk Üniversitesi Sosyal Bilimler Enstitüsü Dergisi, (19), 189-195.

Çelikten, M. (2010). Attitudes toward women school administrators in Turkey. Education, 130(4), 531-540.

Çelikten, M. (2010b). Okul örgütü ve yönetimi, V.Çelik (Ed.), Türk eğitim sistemi ve okul yönetimi (s.121-140). Pegem Akademi, Ankara.

Çetinkanat, A. C., ve Sağnak, M. (2010). İlköğretim ve bakanlık müfettişlerinin iletişim stillerinin karşılaştııılması. Hacettepe Üniversitesi Eğitim Fakültesi Dergisi, 38(38).

Daft, R. L. (2010). Organization theory and design. (10 B.). Mason, $\mathrm{OH}$ : South-Western Cengage Learning.

Dağlı, A. ve Akyıldız, S. (2009) İlköğretim öğretmenlerinin görüşlerine göre ilköğretim denetmenlerinin etik davranışları. Dicle Üniversitesi Ziya Gökalp Eğitim Fakültesi Dergisi, 13, 27-38.

Demirkasımoğlu, N. (2011). Türk eğitim sisteminde bir alt sistem olan denetim sisteminin seçilmiş bazı ülkelerin denetim sistemleri ile karşılaştırılması. Abant İzzet Baysal Üniversitesi Sosyal Bilimler Enstitüsü Dergisi, 23(23), 23-48.

Doğan, D., ve Semerci, N. (2016). Eğitim programlarının uygulanmasında karşılaşılan sorunlar ve sorunların çözümüne ilişkin yönetici görüşleri. Electronic Turkish Studies, 11(9). 
Döş, İ. (2005). Illköğretim düzeyinde kullanılan öğretmen teftiş formunun yeterlik düzeyine ilişkin denetçi, yönetici ve sını öğretmenleri algıları: (Gaziantep Örneği). Gaziantep Üniversitesi, Sosyal Bilimler Enstitüsü, Gaziantep. Yayınlanmamış Yüksek Lisans Tezi.

Duman, A. (1998). Yerinden yönetim mi, yoksa yerelleşme mi? Kuram ve Uygulamada Ĕ̆itim Yönetimi Dergisi, 4(4), 467-483.

Gazete, R. (2014). Millî Eğitim Bakanlığı Rehberlik ve Denetim Başkanlığ1 İle Maarif Müfettişleri Başkanlıkları Yönetmeliği. Resmi Gazete. $Y_{i l}, 24,59-64$.

Glanz, J. (2000). Supervision for the millennium: A retrospective and prospective. Focus On Education, Fall, 9-15, 19 Ekim 2005, 10 Mart 2017, http://www.wagner.edu/faculty/users/jglanz/

Glanz, J., ve Sullivan, S. (2000). Supervision in Practice: 3 Steps to Improving Teaching and Learning. Corwin Press, Inc., A Sage Publications Company, 2455 Teller Road, Thousand Oaks, CA 91320-2218.

Gökçe, D., ve Baskan, G. A. (2012). Eğitim denetçilerinin iletişim becerileri. Hacettepe Üniversitesi Ĕ̆itim Fakültesi Dergisi, 42(42).

Hunt, J. W., ve Baruch, Y. (2003). Developing top managers: the impact of interpersonal skills training. Journal of Management Development, 22(8), 729-752.

Karakuş, M. (2010). Çağdaş denetim yaklaşımları. Fırat Üniversitesi Sosyal Bilimler Dergisi, 20(2).

Kayıkçı, K. (2005). Milli eğitim bakanlığı müfettişlerinin denetim sisteminin yapısal sorunlarına ilişkin algıları ve iş doyum düzeyleri. Hatay milli eğitim müdürlüğü ilköğretim müfettişi. Kuram ve Uygulamada Ĕ̆itim Yönetimi Dergisi. Güz 2005, Sayı 44, Ss: 507-527

Kayıkçı, K., ve Uygur, Ö. (2012). İlköğretim okullarının denetiminde mesleki etik (Bir Durum Çalışması). Kuram ve Uygulamada Ĕ̆itim Yönetimi Dergisi, 18(1), 65-94. 
Korkmaz, M., \& Özdoğan, O. (2005). İlköğretim müfettişlerinin rehberlik görevlerini gerçekleştirme düzeyleri. Türk Ĕ̆itim Bilimleri Dergisi, 3(4), 431-443.

Krohtwolh,D.R. (1993). Medhods of educational and social sciences research: An integrateg apporach. New York: Longman.

Memişoğlu, S. P. (2016). Milli eğitim bakanlığı rehberlik ve denetim başkanlığı ile maarif müfettişleri başkanlıkları yönetmeliğinin lisansüstü öğrencilerinin görüşlerine göre değerlendirilmesi (The Review Of The Regulations Of Ministry Of National Education Counselling And Discipline Department And Education Inspectorship Department İn The View Of Grad Stundents' Opinions). Turkish Studies Dergisi, 11(13), 1703-1722.

Özdemir, T. Y., ve Ozan, M. B. (2013). İlköğretim müfettişlerinin unvanlarında yapılan değişikliğin iş doyumu ve motivasyonlarına etkisi. Firat Üniversitesi Sosyal Bilimler Dergisi, 23(1).

Öztürk, Ş. ve Gök, T. (2010). İlköğretim okullarının kurum denetiminde karşılaşılan sorunlara ilişkin okul müdürlerinin görüşleri (Muğla İli Örneği). II. Uluslararası Katılımlı Eğitim Denetimi Kongresi. 2325 Haziran 2010 Kütahya Dumlupınar Üniversitesi.

Pehlivan, İ. (1997). Eğitim yöneticilerinin etik davranışları üzerine bir araştırma (Ankara ili örneği). Ankara Üniversitesi, Ankara: (Yayımlanmamış Doktora Tezi.

Schermerhorn, J. R., Hunt, J. G., Osborn, R. N., ve Uhl-Bien, M. (2010). Organizational behavior (11. b.). Hoboken, NJ: John Wiley \& Sons.

Sullivan, S., ve Glanz, J. (2005). Supervision that improves teaching: Strategies and techniques. Corwin Press.

Taymaz, H. (2005). Eğitim sisteminde teftiş. Pegem A Yayıncılık, Ankara.

Terzi, Ç. (2011). Türk eğitim sisteminde okulların örgüt ve yönetim yapısı ile yapılandırmacı eğitim yaklaşımı arasındaki ilişkinin çözümlenmesi. Anadolu Journal Of Educational Sciences International, 1(1). 
Toprak, E. ve Bozgeyikli, H. (2011). Öğretmen adaylarının sosyal sermaye düzeylerinin karşılaştırmalı incelenmesi (Erciyes Üniversitesi Örneği). Erciyes Üniversitesi Sosyal Bilimler Enstitüsü Dergisi, 2(31), 125-147.

Uğurlu, C. T. (2010a) Öğretmenlerin ilköğretim müfettişlerinin etik davranışlarına ilişkin görüşleri ve örnek olaylar. II. Uluslararası Katılımlı Eğitim Denetimi Kongresi. 23-25 Haziran 2010 Kütahya Dumlupınar Üniversitesi.

Whetten, D. A., ve Cameron, K. S. (1993). Developing management skills: Developing self-awareness. Harpercollins College Div.

Yaman, E. (2010). Müfettişlerin rehberlik rollerini rehber öğretmenler değerlendiriyor, Guidance Teachers Evaluate The Guidance Role Of Supervisors.

Yıldız, D. Ç. (2015). Yönetici ve öğretmen görüşlerine göre maarif müfettişlerinin konuşma becerilerinin değerlendirilmesi. Evaluation of supervisors'speaking skills according to comments of principles and teachers. Mustafa Kemal Üniversitesi Sosyal Bilimler Enstitüsü Dergisi, 12(31).

\section{Kaynakça Bilgisi / Citation Information}

Özkan, H. H. ve Çelikten Y. (2017). Milli eğitim sisteminin örgütsel yapısı ve maarif müfettişleri alt sisteminin işleyişi. OPUS- Uluslararası Toplum Araştırmaları Dergisi, 7(13), 965-990. 